\title{
Occupational asthma from nickel sensitivity: I Human serum albumin in the antigenic determinant
}

\author{
J DOLOVICH, S L EVANS, AND E NIEBOER
}

From the Departments of Pediatrics and Biochemistry, Faculty of Health Sciences, McMaster University, Hamilton, Ontario, Canada L8N $3 Z 5$

ABSTRACT Occupational asthma from nickel sensitivity was confirmed in a male worker (SB) by allergy skin tests and inhalational challenge. In an ammonium sulphate coprecipitation test ${ }^{63} \mathrm{Ni}$ was selectively precipitated from SB plasma indicating antibody with nickel related specificity. Preincubation of ${ }^{63} \mathrm{Ni}$ with human serum albumin (HSA) increased the specificity of the coprecipitation test. Blocking experiments with nickel and copper(II) salts effectively inhibited the binding of ${ }^{63} \mathrm{Ni}$ to antibody of SB plasma but did not affect control tests or that for antibodies to an unrelated antigen, ampicillin. $\mathrm{Co}^{2+}$ slightly inhibited the binding of ${ }^{63} \mathrm{Ni}$, while $\mathrm{Zn}^{2+}$ and $\mathrm{Mn}^{2+}$ failed to inhibit. This deactivation pattern corresponds to the known sequence of binding of these metals to the primary copper binding site of HSA. It is concluded that the antigenic determinant depends on the combination of $\mathrm{Ni}^{2+}$ with HSA at this specific copper/nickel plasma transport site.

Occupational asthma induced by low molecular weight substances is an increasing problem. The general features of the pathogenesis of asthma on an immunological basis due to IgE antibody are reasonably well understood. ${ }^{1}$ By contrast, asthma induced by reactive chemicals such as toluene diisocyanate (TDI) is poorly understood and most cases are unassociated with a detectable immune response. ${ }^{2}$ Most of these chemically reactive inducers of asthma are new to the human experience and, at least in part, account for the apparent increase in frequency of the disease. One possible explanation for the failure to account for the disease by the demonstration of antibodies is a use of inappropriate antigen preparations.

McConnell et al were the first to document a case of asthma associated with the inhalation of nickel salts. ${ }^{3}$ Earlier, an incident of nickel related asthma due to exposure to nickel carbonyl had occurred in a patient with Löffler's syndrome. ${ }^{4}$ More recently, two additional case studies have appeared, ${ }^{56}$ including our own. ${ }^{5}$ Generally, the patients exhibited dermatitis and a positive allergy skin test to nickel salts and responded to an inhalation challenge with nickel sulphate. McConnell et al concluded from skin and haemagglutination tests that circulating antibody to nickel was implicated. ${ }^{3}$ Our findings appear to

Received 15 November 1982

Accepted 10 January 1983 confirm this conclusion, as the patient's serum reacted in a Ni-HSA radioallergosorbant test for antibodies of the IgE class. In addition, in an ammonium sulphate coprecipitation $(\text { Farr })^{7}$ test with ${ }^{63} \mathrm{Ni}$, more label was precipitated from his plasma than control plasma specimens, further indicating the presence of antibody with Ni specificity. ${ }^{5}$ Coupling of $\mathrm{Ni}^{2+}$ with human serum albumin (HSA) appears to be required for antigenic activity. The correlative roles of $\mathrm{Ni}^{2+}$ and $\mathrm{HSA}$ in the antigenic determinant are explored in detail in this and a companion paper. ${ }^{8}$ Although occupational asthma due to antibodies with nickel related specificity is uncommon, the immunological principles evolved from our work should enhance our understanding of more common antibody dependent reactivity to metals, particularly to platinum. ${ }^{910}$

\section{Binding of $\mathbf{N i}^{2+}$ to $\mathrm{HSA}$}

Binding of $\mathrm{Ni}^{2+}$, including that in serum, to HSA, has been shown at physiological $\mathrm{pH}$ values. ${ }^{112}$ Autoradiography experiments in basic solution $(\mathrm{pH}$ 8.6) have shown that $\mathrm{Ni}^{2+}$ occupies the primary copper binding site of HSA. ${ }^{13}$ Judging from spectrophotometric data for the formation of the $\mathrm{Ni}$-HSA complex ${ }^{814}$ and the magnitude $(6 \times$ $10^{5} \mathrm{M}^{-1}$, but see ref 14 ) of the corresponding association constant at $\mathrm{pH} 7 \cdot 5$, this mode of complexing is 
also important at $\mathrm{pH} 7 \cdot 4 .{ }^{11} 1516$

The primary copper binding site of HSA consists of a square-planar chelate ring formed by the $\mathrm{N}$-terminus $\alpha$-amino nitrogen, the first two peptide nitrogens, and the 3-nitrogen of the imidazole ring of residue $3 . .^{1517}$ This site is common to several albumins including bovine, human, and rat. ${ }^{118}$ Metal ion competition studies have shown that a threefold excess of $\mathrm{Ni}^{2+}$ suppressed the $\mathrm{Cu}^{2+}$ occupancy at this site to $5 \%$ (for comparison, the $\mathrm{Cu}^{2+}$ association constant is $9 \times 10^{6} \mathrm{M}^{-1}$, but see ref 14). ${ }^{131519}$ By contrast, the same excess of $\mathrm{Co}^{2+}$ replaced only $50 \%$ of the $\mathrm{Cu}^{2+}$. Interestingly, $\mathrm{Zn}^{2+}$ did not compete with the $\mathrm{Cu}^{2+}$ and, like $\mathrm{Mn}^{2+}$, is suspected to have a different mode of attachment. ${ }^{152-22}$ Because of these divergent affinities for HSA, metal ion competition studies were considered potentially applicable to the characterisation of the $\mathrm{Ni}^{2}+\mathrm{HSA} /$ antibody interactions.

\section{Materials and methods}

\section{COLLECTION OF SAMPLES}

Serum and ACD plasma were obtained from a worker (SB) in whom occupational asthma from the inhalation of nickel sulphate had been proved by inhalation challenge. ${ }^{5}$ Control serum specimens were obtained from seven laboratory workers with no occupational exposure to Ni. Two ACD plasma specimens were obtained from the local Red Cross blood transfusion service; one was group $A, R h$ negative and the other was group $B, R h$ negative.

\section{EFFECT ON HSA OF THE ANTIBODY COPRECIPITATION TEST}

The ammonium sulphate ${ }^{63} \mathrm{Ni} /$ antibody coprecipitation (Farr) test included routine procedures. ${ }^{723}$ The effect of preincubating the labelled $\mathrm{Ni}^{2}+$ with HSA was examined in the following manner. Twenty microlitres of HSA $(1 \mathrm{mg} / \mathrm{ml}$ distilled water) or distilled water were incubated with $100 \mu \mathrm{l}$ of ${ }^{63} \mathrm{Ni}$, diluted 1/10 000 with borate-saline buffer $(\mathrm{pH} \mathrm{8.3,}$ $0.10 \mathrm{M} \mathrm{H}_{3} \mathrm{BO}_{3}, 0.025 \mathrm{M}$ Borax, 0.075 M NaCl) from prepared stock $\left({ }^{63} \mathrm{NiCl}_{2}\right.$, New England $\mathrm{Nu}$ clear, $7 \times 10^{-4} \mathrm{M} \mathrm{Ni}, 2 \mathrm{mCi}$ in $0.2 \mathrm{ml}$ of $0.5 \mathrm{M} \mathrm{HCl}$; and diluted to $5.0 \mathrm{ml}$ with distilled water). The ${ }^{63} \mathrm{Ni}-\mathrm{HSA}$ or control mixtures were incubated at room temperature for two hours and then $0.1 \mathrm{ml}$ test serum was added. After overnight incubation at $4^{\circ} \mathrm{C}$, $0.78 \mathrm{ml}$ of the borate buffer and $1.0 \mathrm{ml}$ of saturated ammonium sulphate were pipetted in. After centrifugation, the precipitate was washed with $50 \%$ $\left(\mathrm{NH}_{4}\right)_{2} \mathrm{SO}_{4}$, in borate-saline, and the radioactivity was then measured by liquid scintillation spectrometry after allowing the ${ }^{63} \mathrm{Ni}$ to stabilise in the counting cocktail overnight. ${ }^{23}$

\section{METAL ION COMPETITION STUDIES}

Blocking by metal ions of the ammonium sulphate ${ }^{63} \mathrm{Ni} /$ antibody coprecipitation test was studied using the following procedure. Twenty microlitres of the appropriate metal salt solution $\left(10^{-6}\right.$ to $10^{-2} \mathrm{M}$ in distilled water, or in the case of $\mathrm{Cr}^{3+}$ in $10^{-2} \mathrm{M}$ $\mathrm{HNO}_{3}$ ) were incubated overnight at ambient temperature with $100 \mu \mathrm{l}$ of plasma. Subsequently, 120 $\mu l$ of a ${ }^{63} \mathrm{Ni} / \mathrm{HSA}$ mixture $\left(10 \mathrm{ml}\right.$ of ${ }^{63} \mathrm{Ni}$ diluted in borate-saline buffer at $\mathrm{pH} 8.3$ incubated for two hours with $2 \mathrm{ml}$ of $1 \mathrm{mg} / \mathrm{ml} \mathrm{HSA}$ ) was added. After overnight incubation at $4^{\circ} \mathrm{C}$, the $\left(\mathrm{NH}_{4}\right)_{2} \mathrm{SO}_{4}$ coprecipitation test was carried out as before.

\section{Results}

Preincubation of ${ }^{63} \mathrm{Ni}$ with HSA before addition to SB serum, in the ammonium sulphate coprecipitation test, had little effect on the precipitation of ${ }^{63} \mathrm{Ni}$ (fig 1). This contrasts with the major reduction in the precipitation of ${ }^{63} \mathrm{Ni}$ from control sera.

Inhibition by nickel, copper, and cobalt salts of ${ }^{63} \mathrm{Ni}$ coprecipitation with SB plasma is illustrated in fig 2a. On a molar basis, $\mathrm{NiSO}_{4}$ had the most potent blocking effect followed by $\mathrm{CuSO}_{4}$ and then $\mathrm{Co}\left(\mathrm{NO}_{3}\right)_{2}$. In separate experiments $\mathrm{NiCl}_{2}$ and $\mathrm{Ni}\left(\mathrm{NO}_{3}\right)_{2}$ were shown to be comparable with $\mathrm{NiSO}_{4}$. From experiment to experiment, the absolute counts for SB and control samples varied slightly due to

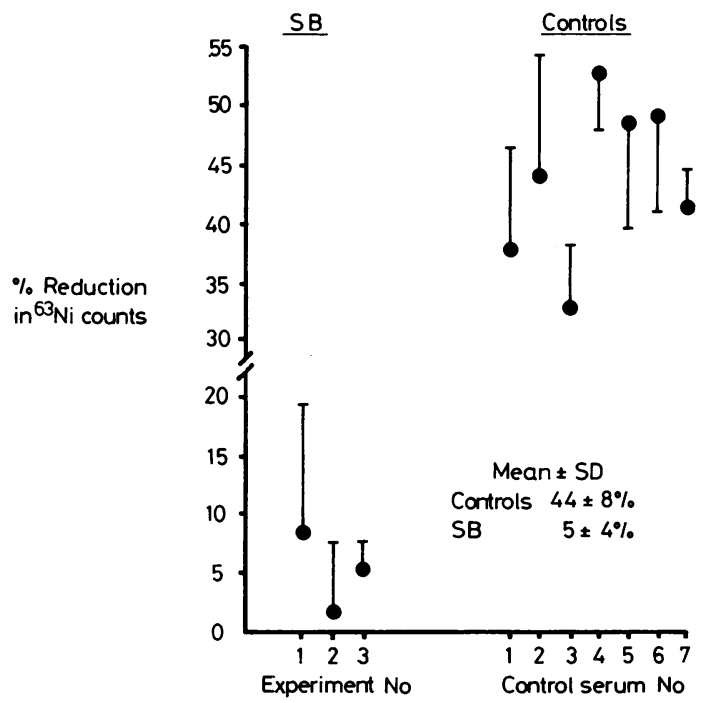

Fig 1 Infuence of HSA on coprecipitation of ${ }^{63} \mathrm{Ni}$. Serum samples were incubated with preformed ${ }^{63} \mathrm{Ni}-\mathrm{HSA}$ before ammonium sulphate coprecipitation test. Error bars shown correspond to relative standard error for two to six replicates calculated from variances of component terms. 
(a)

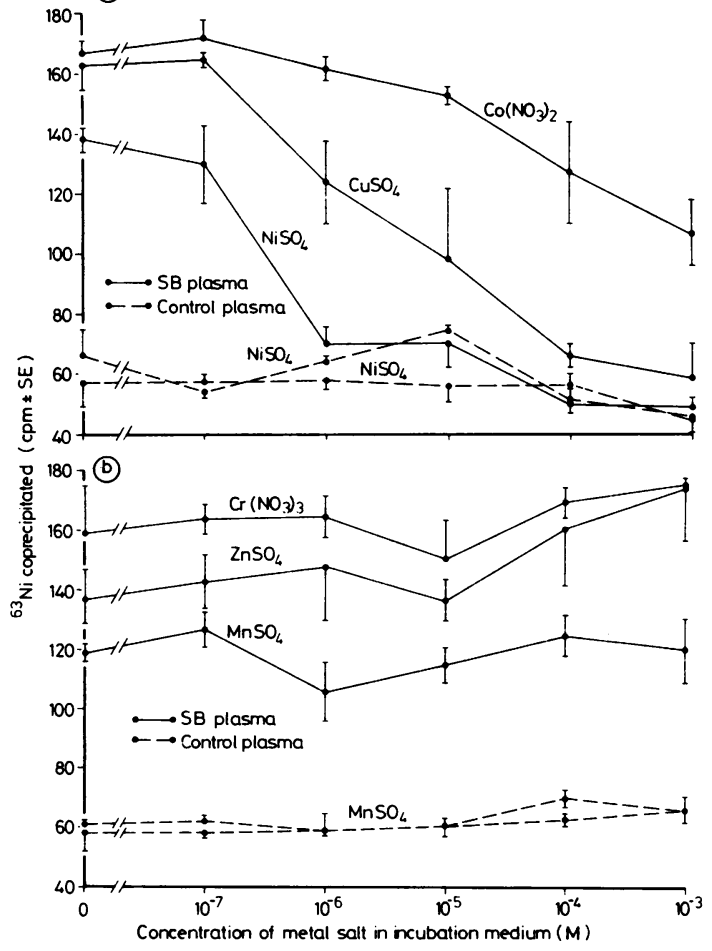

Fig 2 Blocking of ammonium sulphate ${ }^{63}$ Ni/antibody coprecipitation test by metal salts. Plasma samples were incubated with metal salt before addition of the ${ }^{63} \mathrm{Ni}-\mathrm{HSA}$ complex. Coprecipitation test was carried out subsequently. (a) Inhibition by $\mathrm{Co}^{2+}, \mathrm{Cu}^{2+}$, and $\mathrm{Ni}^{2+}$. As shown for $\mathrm{NiSO}_{4}, \mathrm{Co}^{2+}$, and $\mathrm{Cu}^{2+}$ salts did not induce inhibition in control samples. (b) Lack of inhibition by $\mathrm{Cr}^{3+}, \mathrm{Zn}^{2+}$, and $\mathrm{Mn}^{2+}$. As shown for $\mathrm{MnSO}_{4}, \mathrm{Cr}^{3+}$ and $\mathrm{Zn}^{2+}$ salts did not effect control plasma samples. Vertical bars denote standard errors corresponding to three replicate samples.

settling of the protein precipitate in the liquid scintillation cocktail mixture. This process did not alter the shape of the inhibition or control curves.

The $\mathrm{NiSO}_{4}, \mathrm{CuSO}_{4}$, and $\mathrm{Co}\left(\mathrm{NO}_{3}\right)_{2}$ had no effect on the precipitation of ${ }^{63} \mathrm{Ni}$ in tests with the two control plasma specimens. Moreover, these salts did not affect coprecipitation of an immunologically unrelated antigen with its corresponding antibodies. Thus, for the same concentration range, these salts produced no blocking of the antibody related coprecipitation of a labelled ampicillin-HSA reagent in the ammonium sulphate coprecipitation test.

$\mathrm{Cr}\left(\mathrm{NO}_{3}\right)_{3}, \mathrm{ZnSO}_{4}$, and $\mathrm{MnSO}_{4}$ had no affect on the precipitation of ${ }^{63} \mathrm{Ni}$ from SB antibody containing plasma or from control plasma specimens (fig 2b).

\section{Discussion}

\section{EFFECT OF HSA ON THE ANTIBODY} COPRECIPITATION TEST

The observed reduction (fig 1) in binding of labelled $\mathrm{Ni}$ to normal human sera as a consequence of prior addition of HSA denotes reduced availability of the ${ }^{63} \mathrm{Ni}^{2+}$ for non-specific protein binding in the coprecipitation test. This decrease would also apply to SB serum. Thus the relatively small change in counts actually observed with SB serum is taken to indicate a concomitant equalising increase in specific antibody binding by this antibody containing serum. The quantity of HSA added to the labelled $\mathrm{Ni}$ before incubation with serum corresponded to $1 / 200$ the quantity of HSA present in the test serum aliquot. Consequently, it may be concluded that the preformation of the ${ }^{63} \mathrm{Ni}^{2}+/ \mathrm{HSA}$ complex, rather than simply an HSA concentration increase was responsible for the enhancement of interaction of ${ }^{63} \mathrm{Ni}$ with antibody. Data on the $\mathrm{pH}$ dependence of the coprecipitation test for SB plasma reported in part II confirm this; they parallel that for the formation of the primary $\mathrm{Ni}^{2+} / \mathrm{HSA}$ complex. ${ }^{814}$ On a more practical note, the use of HSA preincubation improved the specificity of the coprecipitation antibody test and was subsequently incorporated into the procedure.

\section{METAL ION COMPETITION STUDIES}

Excellent agreement was observed for SB plasma between the blocking effectiveness by metal ions and their known affinity for the primary copper binding site of HSA. There was blocking by $\mathrm{Ni}^{2+}$, $\mathrm{Cu}^{2+}$, and $\mathrm{Co}^{2+}$ but not by $\mathrm{Zn}^{2+}, \mathrm{Mn}^{2+}$, and $\mathrm{Cr}^{3+}$. Furthermore, there was no anion $\left(\mathrm{Cl}^{-}, \mathrm{NO}_{3}^{-}\right.$, $\mathrm{SO}^{2-}{ }_{4}$ ) dependence. Metal ion or anion inhibitory effects were not observed for control samples. $\mathrm{Ni}^{2+}$ and $\mathrm{Cu}^{2+}$ had no effect on labelled antigen binding in an ammonium sulphate coprecipitation test of serum with antiampicillin antibodies performed with labelled HSA-ampicillin reagent (see part II). ${ }^{8}$ These observations show that the antigenic determinant recognised by antibody in SB plasma required the occupation of the primary copper binding site of $\mathrm{HSA}$ by $\mathrm{Ni}^{2+}$. When $\mathrm{Ni}^{2+}$ was displaced but remained in the reaction mixture binding to antibody diminished.

\section{Ni/HSA COMPLEX IN THE ANTIGENIC DETERMINANT}

The patient's sensitivity therefore seems to depend on the interaction of $\mathrm{Ni}^{2+}$ with a native binding site on HSA and would appear to result from a unique host susceptibility. The molecular configuration of the Ni-HSA complex would presumably be "normal" but present in greater concentration in SB as a 
result of the high occupational exposure to soluble nickel salts. Plasma $\mathrm{Ni}^{2+}$ concentrations are known to be enhanced in workers exposed to nickel in electroplating processes. ${ }^{2425}$ The greater inhibitory effect of non-labelled $\mathrm{Ni}^{2+}$ compared with $\mathrm{Cu}^{2+}$ exhibited in fig $2 \mathrm{a}$ is surprising since the $\mathrm{Cu}^{2+} / \mathrm{HSA}$ interaction is stronger by at least a factor of 15 (see association constants quoted above). This observation implies that the strength of the $\mathrm{Ni}^{2+}, \mathrm{HSA} /$ antibody interaction depends on a special structural feature of the interaction of $\mathrm{Ni}^{2+}$ with HSA.

\section{IMPLICATIONS}

HSA was used as the binding protein in these experiments because we have knowledge of the specific binding site for $\mathrm{Cu}^{2+}$ and $\mathrm{Ni}^{2+}$. In individuals reacting to other low molecular weight substances alternative host components might be more relevant, although in the case of the metal sensitiser platinum, the reactive RAST antigen was Pt reacted with HSA. ${ }^{10}$ Recently, a specificity of antibody for trimellitic anhydride (TMA)-modified secretory IgA has been postulated for individuals with TMA induced occupational asthma. ${ }^{26}$ Specificity for carrier HSA has also recently been reported for antibodies to TDI and TMA. ${ }^{26}{ }^{27}$ This does not constitute interaction dependent on a normal physiological binding site on the protein comparable to the $\mathrm{Cu}^{2+}$ binding site on HSA. Nevertheless, TDI or TMA induced modification or denaturation could occur in vivo and represent the molecular basis for the stimulation of antibody and the resulting sensitisation. Thus alterations of host components may be on the basis of a normal binding site provided by the host or a denaturation produced by highly chemically reactive inhaled molecules such as TDI and TMA. Regardless, the recognition that the novel antigenic determinants yielded by these alterations can potentially be a basis of sensitisation may well usher in new approaches to the unravelling of the pathogenesis of reactions to environmental substances including those leading to occupational asthma. We are currently investigating the possibility that the requirement of the Ni/HSA complex for immunological reactivity could also apply to cellular immune responses operative in contact dermatitis and reactions to metal prostheses. The leukocyte migration test indicates that this may be so. ${ }^{28}$ Thus comparable mechanisms pertaining to antigenic specificity may well be involved in both humoural and cellular responses to nickel, and by analogy, presumably also to cobalt, platinum, and other metals. Clarification of these issues might be expected to improve the laboratory tests available to identify sensitised individuals.
We thank Drs J-L Malo and A Cartier, Hôpital du Sacré-Coeur, Montréal, for the supplies of SB plasma and serum. Financial support from the Natural Sciences and Engineering Research Council of Canada is gratefully acknowledged.

\section{References}

1 Newman Taylor AJ. Occupational asthma. Thorax 1980;35: 241-5.

${ }^{2}$ Pepys J. Occupational asthma: review of present clinical and immunologic status. J Allergy Clin Immunol 1980;66:179-85.

${ }^{3}$ McConnell LH, Fink JN, Schlueter DP, Schmidt MG Jr. Asthma caused by nickel sensitivity. Ann Intern Med 1973;78:888-90.

4 Sunderman FW, Sunderman FW Jr. Loffler's syndrome associated with nickel sensitivity. Arch Intern Med 1961;107:405-8.

5 Malo J-L, Cartier A, Doepner M, Nieboer E, Evans SL, Dolovich J. Occupational asthma caused by nickel sulfate. $J$ Allergy Clin Immunol 1982;69:55-9.

- Block GT, Yeung M. Asthma induced by nickel. JAMA 1982;247:1600-2.

${ }^{7}$ Minden P, Farr RS. The ammonium sulfate method to measure antigen-binding capacity. In: Wier DM, ed. Handbook of experimental immunology. Oxford: Blackwell Scientific Publications, 1967:463-92.

${ }^{8}$ Nieboer E, Evans SL, Dolovich J. Occupational asthma from nickel sensitivity: II Factors influencing the interaction of $\mathrm{Ni}^{2+}, \mathrm{HSA}$, and serum antibodies with nickel related specificity. Br J Ind Med 1983;41:56-63.

${ }^{9}$ Roto P. Asthma, symptoms of chronic bronchitis and ventilatory capacity among cobalt and zinc production workers. Scand J Work Environ Health 1980;6, suppl 1:1-49.

${ }^{10}$ Cromwell O, Pepys J, Parish WE, Hughes EG. Specific IgE antibodies to platinum salts in sensitized workers. Clin Allergy 1979;9:109-17.

" Callan WM, Sunderman FW. Species variations in binding of ${ }^{63} \mathrm{~N}$ (II) by serum albumin. Res Commun Chem Pathol Pharmacol 1973;5:459-72.

12 Lucassen M, Sarkar B. Nickel(II)-binding constitutents of human blood serum. J Toxicol Environ Health 1979;5:897-905.

${ }^{13}$ Peters T. Serum albumin: recent progress in the understanding of its structure and biosynthesis. Clin Chem 1977;23:5-12.

${ }^{14}$ Glennon JD, Sarkar B. Nickel(II) transport in human blood serum. Biochem J 1982;203:15-23.

${ }^{15}$ Peters T. Serum albumin. In: Putnam FW, ed. The plasma proteins: structure, function and genetic control. Vol 1. 2nd ed. New York: Academic Press, 1975:133-81.

${ }^{16}$ Peters T, Blumenstock FA. Copper-binding properties of bovine serum albumin and its amino-terminal peptide fragment. $J$ Biol Chem 1967;242:1574-8.

${ }^{17}$ Peters T. Serum albumin. Adv Clin Chem 1970;13:37-111.

${ }^{18}$ Dixon JW, Sarkar B. Absence of a specific copper(II) binding site in dog albumin is due to amino acid mutation in position 3 . Biochem Biophys Res Commun 1972;48:197-200.

${ }^{19}$ Kolthoff IM, Willeford BR. The interaction of $\mathrm{Cu}$ (II) with bovine serum albumin. Journal of the American Chemical Society 1958;80:5673-8.

${ }^{20}$ Perkins DJ. Studies on the interaction of zinc, cadmium and mercuric ions with native and chemically modified human serum albumin. Biochem J 1961;80:668-72.

${ }^{21}$ Rao MSN, Lal H. Metal protein interactions in buffer solutions Part III. Interaction of $\mathrm{Cu}^{\mathrm{II}}, \mathrm{Zn}^{\mathrm{II}}, \mathrm{Cd}^{\mathrm{II}}, \mathrm{Co}^{\mathrm{II}}$ (and $\mathrm{Ni}^{\mathrm{II}}$ ) with native and modified bovine serum albumins. Journal of the American Chemical Society 1958;80:3226-35.

${ }^{22}$ Nandedkar AKN, Nurse CE, Friedberg F. $\mathrm{Mn}^{++}$binding by plasma proteins. Int J Pept Protein Res 1973;5:279-81.

${ }^{23}$ Kasprzak KS, Sunderman FW. Radioactive ${ }^{63} \mathrm{Ni}$ in biological research. Pure and Applied Chemistry 1979;51:1375-89. 
${ }^{24}$ Bernacki EJ, Parsons GE, Roy BR, Mikac-Devic M, Kennedy $\mathrm{CD}$, Sunderman FW. Urine nickel concentrations in nickelexposed workers. Ann Clin Lab Sci 1978;8:184-9.

${ }^{25}$ Tola S, Kilpiö J, Virtamo M. Urinary and plasma concentrations of nickel as indicators of exposure to nickel in an electroplating shop. JOM 1979;21:184-8.

${ }^{26}$ Zeiss CR, Levitz D, Pruzansky JJ, Patterson R. Antibody to haptenized human serum albumin and human secretory IgA in workers exposed to trimellitic anhydride (TMA) [abstract]. $J$ Allergy Clin Immunol 1982;69:123.

${ }^{27}$ Butcher BT, Mapp C, Reed MA, O'Neil CE, Salvaggio JE. Evidence for carrier specificity of $\mathrm{IgE}$ antibodies detected in sera of isocyanate exposed workers [abstract]. J Allergy Clin Immunol 1982;69:123.

${ }^{2 *}$ Thulin $\mathrm{H}$. The leukocyte migration test in nickel contact dermatitis. Acta Dermatovener (Stockholm) 1976;56:377-80. 